\title{
Overall Performance Evaluation of select Microfinance Institutions - an Empirical Analysis
}

\author{
${ }^{1}$ Dr. S. Narasimha Chary, ${ }^{2}$ Dr. Sreenivas Savvasi, ${ }^{3}$ A. Swapna Rani \\ ${ }^{1}$ Assistant Professor of Commerce \& Business Management, Kakatiya University, Warangal. \\ ${ }^{2}$ Faculty Member, Dept. of Commerce \& Business Management, GVJC, Hanamkonda, Warangal. \\ ${ }^{3}$ Faculty Member, Dept. of Economics, Maharshi Degree \& PG College, Mulugu, Warangal.
}

\begin{abstract}
Microfinance firms are viewed predominantly as instruments of social change, their performance has been often measured by non-financial parameters. The concept of social performance has seemed to overshadow the state of financial health of these enterprises. A microfinance institution is measured for financial sustainability based on its good financial accounts and the recognized accounting practices. The main objectives of this paper are to study the Brief Profile of Select Microfinance Institutions, to review the Overall Performance of select MFIs and to evaluate the Yield on Gross Portfolio of Select Microfinance Institutions. The data collected for the study includes secondary data. The various sources used to collect secondary data include research papers, journals, Status of Microfinance in India reports published by NABARD and various other websites. The secondary data collected is analyzed using various statistical tools and techniques such as one way ANOVA. The technique is used to identify if there exist a significant difference in the mean of different of select MFIs. As such, it has been observed based on the analysis that the average yield on gross portfolio of SML (27.81 per cent), BSFL (24.30 per cent), CMC (24.15 per cent), GVMFL (31.38 per cent), and GFSPL (28.57 per cent) recorded above the industry aggregate average (23.93 per cent), which depicts that these MFIs were relatively different in achieving high yielding on gross portfolio as compared to that of other MFIs.
\end{abstract}

Key Words: Mf, Mfis, Nabard, Yield on Gross Portfolio.

\section{Introduction}

As microfinance firms are viewed predominantly as instruments of social change, their performance has been often measured by non-financial parameters. The concept of social performance has seemed to overshadow the state of financial health of these enterprises. A microfinance institution is measured for financial sustainability based on its good financial accounts and the recognized accounting practices ${ }^{1}$.

Microfinance Institutions have been expected to reduce poverty, which is considered as the most important development objective (World Bank, 2000) ${ }^{1}$. In India, there does not seem to be any working model of analyzing the financial performance and thereby sustainability of microfinance institutions. This problem is compounded by the absence of a dedicated legislation on working and management of microfinance institutions. The lack of a regulatory mechanism for financial disclosures by microfinance institutions also abets the problem.

The present paper attempts to analyze the financial performance of various microfinance institutions operating in India. It assumes significance because it is imperative that these institutions be run efficiently given the fact that they are users of marginal and scarce capital and the intended beneficiaries are the marginalized sections of society. MFIs must be able to sustain themselves financially in order to continue pursuing their lofty objectives, through good financial performance.

\section{Objectives of the paper:}

* To study the Brief Profile of Select Microfinance Institutions

* To study the Overall Performance of select MFIs

* To evaluate the Yield on Gross Portfolio of Select Microfinance Institutions

\section{Methodology:}

The data collected for the study includes secondary data. The various sources used to collect secondary data include research papers, journals, Status of Microfinance in India reports published by NABARD and various other websites. The secondary data collected is analyzed using various statistical tools and techniques

\footnotetext{
${ }^{1}$ Meyer, R.L. (2002), Track Record of Financial Institutions in Assisting the Poor in Asia., ADB Institute Research Paper, No. 49, December 2002.

${ }^{2}$ World Bank. (2003), “Microfinance in India: Issues, Challenges and Policy Options.” Washington D.C.: World Bank.
} 
such as one way ANOVA. The technique is used to identify if there exist a significant difference in the mean of different of select MFIs.

For the purpose of analysis, a sample size of ten microfinance institutions has been chosen. The companies taken for the study purpose are:

1. SKS Microfinance Ltd (SKSMPL)

2. Spandana Sphoorty Financial Ltd (SSFL)

3. Share Microfin Limited (SML)

4. Asmitha Microfin Ltd (AML)

5. Sri Kshetra Dhamasthala Rural Development Project (SKDRDP)

6. Bharatiya Samruddhi Finance Limited (BSFL)

7. Bandhan Society (BS)

8. Cashpor Micro Credit (CMC)

9. Grama Vidiyal Microfinance Pvt. Ltd. (GVMFL)

10. Grameen Financial Services Pvt. Ltd. (GFSPL)

\section{SKS Microfinance Ltd (SKSMPL):}

SKS Microfinance Ltd. (SKSMPL) is India's largest microfinance institution (MFI) with a member base of 5 million borrowers as on September 30, 2011. It was incorporated as a private limited company in 2003 for taking over the microfinance activities of Swayam Krishi Sangam (SKS), a society that was registered in 1997 and began operations in 1998. After obtaining the non banking financial company (NBFC) license from the Reserve Bank of India in January 2006, SKSMPL took over the operations of SKS.

The company follows the group-lending model, which closely resembles Bangladesh-based Grameen Bank's model. While group loans have tenure of 50 weeks, individual loans bear a term of 12 to 24 months. SKSMPL charge an interest rate of 23.6 per cent on a declining method basis in Andhra Pradesh and Karnataka and 28 per cent in other states.

\begin{tabular}{|l|l|}
\hline Years of incorporation : & 2003 \\
\hline Years of commencement of Microfinance operations : & 1998 \\
\hline Legal status : & Private Ltd. Co. (NBFC) \\
\hline Lending model : & JLG \\
\hline Chief Executive : & Mr. Suresh Gurumani, Chief Executive officer \\
\hline Auditor : & S.R. Batliboi \& Co., Hyderabad \\
\hline
\end{tabular}

\section{Spandana Sphoorty Financial Ltd (SSFL):}

Spandana Sphoorty Financial Ltd. (SSFL) was incorporated in 2003 as Spandana Sphoorty Innovative Financial Services Ltd (SSIFSL), non-banking financial company, by the promoter's portfolio to SSIFSL in 2004-05. SSIFSL was renamed in 2007-08.

SSFL is the second-largest microfinance institution (MFI) in the country. In terms of loans outstanding as on September 30, 2011, the company had a loan outstanding of Rs.23.98 billion and operations in eight states. SSFL follows the hybrid group and Grameen Bank lending models. The company offers five types of loans with lending rates ranging from 21 to 24 per cent on a declining methods basis. SSFL also offers credit-plus services.

\begin{tabular}{|l|l|}
\hline Year of Incorporation : & 2003 \\
\hline Year of commencement of microfinance operations: & 1998 \\
\hline Legal status: & Public Ltd. Co. (NBFC) \\
\hline Lending model: & JLG, individual \\
\hline Chief Executive : & Ms. Padmaja Reddy, Managing Director \\
\hline Auditor : & BSR \& Company, Hyderabad \\
\hline
\end{tabular}

\section{SHARE Microfin Ltd (SML):}

SHARE Microfin Ltd. (SML) is India's third-largest microfinance institution (MFI), with a loan outstanding of Rs.18.57 billion and 3.6 million borrowers as on September 30, 2011. SML was the first MFI in India to transform into an NBFC from a non-profit legal outfit in 1999-00 and is credited for successfully replicating Bangladesh-based Grameen Bank's group lending model in India. SML started operations by taking over the branch network of the society for Helping Awaking Rural poor through Education (SHARE) in January 2000. As on September 30, 2011, SML has operations in 142 districts across 16 states. During the past few years, the company's ownership profile has changed from a community-owned entity to an entity with institutional ownership with the equity investment of US \$ 27 million by Legatum Ventures Ltd. and Avaishkaar Good well India Microfinance Development Co. Limited in 2007. 
The company, which offers four types of loan products, disburses its micro loans ranging between a period of 12 months and 24 months, and charges a flat 12-14 per cent interest rate.

\begin{tabular}{|l|l|}
\hline Year of Incorporation : & 1999 \\
\hline Year of commencement of microfinance operations: & 2000 \\
\hline Legal status: & Public Ltd. Co. (NBFC) \\
\hline Lending model: & JLG, individual \\
\hline Chief Executive : & Mr. M. Udaya Kumar, Managing Director \\
\hline Auditor : & S. R. Batliboi \& Co., Hyderabad \\
\hline
\end{tabular}

\section{Asmitha Microfin Ltd (AML):}

Asmitha microfin Ltd. (AML), an NFBC, began its microfinance operations in 2002, it is one of the top five microfinance institutions (MFIs) in India. AML lends to five-member groups of women under Grameen Bank model, at a flat interest rate of 12.5 per cent to 15 per cent, and charges an upfront one-time processing 1.15 to 2.50 per cent of the loan amount.

AML has a strong rural presence. Most of the loans are given for income-generation activities, trading and animal husbandry account for about two-thirds of AML loans. As of March 31, 2008, AML was present in Orissa, Andhra Pradesh, Karnataka, and Maharashtra. It has ventured into nine more states during 2008-09.

\begin{tabular}{|l|l|}
\hline Year of Incorporation: & 2001 \\
\hline $\begin{array}{l}\text { Year of commencement of microfinance } \\
\text { operations: }\end{array}$ & 2002 \\
\hline Legal status: & Public Ltd. Co. (NBFC) \\
\hline Lending model: & JLG \\
\hline Chief Executive : & $\begin{array}{l}\text { Dr. Vidya Sravanthi, Chairperson \& Managing } \\
\text { Director }\end{array}$ \\
\hline Auditor: & S. R. Batliboi \& Co., Hyderabad \\
\hline
\end{tabular}

\section{Shri Kshetra Dharmasthala Rural Development Project (SKDRDP):}

Established in 1982 by Dr. D Veerendra Heggade, a trustee of the Shri Kshetra Dharmasthala, Shri Kshetra Dharmasthala Rural Development Project (SKDRDP) is a charitable trust. SKDRDP offers structured products with a focus on livelihood support and asset creation. Loans are disbursed to SHGs at an interest rate of 15 per cent annum on a declining method basis. The loan tenure ranges between three and 10 years. Borrowers also have to pay 1 per cent of the loan amount towards service charges.

As on September 30, 2011, SKDRDP had 22 branches, covering 4,739 Villages, 7,64,351 members (of which 612,482 were borrowers) from 76,662 SHGs. The microfinance institution (MFI) has operations in six districts of Karnataka- Udipi, Daksina Kannada, Shimoga, Chikmagalur, Korg, and Uttara Kannada. This MFI is a non governmental organization (NGO).

\begin{tabular}{|l|l|}
\hline Year of Incorporation : & 1982 \\
\hline Year of commencement of microfinance operations: & 1995 \\
\hline Legal status: & Trust \\
\hline Lending model: & SHG \\
\hline Chief Executive : & Dr. L H Manjunath, Executive Director \\
\hline Auditor : & Rao and Basari Co, Mangalore \\
\hline
\end{tabular}

\section{Bhartiya Samruddhi Finance Ltd (BSFL):}

Bhartiya Samruddhi Finance Ltd. (BSFL), an NBFC promoted by Bhartiya Samruddhi investment sand consulting services Ltd. (BASICS), started operations in 1997. BSFL is one of the pioneers in extending orgainzed microfinance to those without access to banking and financial services. The company has more than decade of experience in microfinance, and has disbursed more than Rs.16 billion of loans since inception. BSFL adopts diverse lending models (loans to individuals, joint-liability groups of farmers and federations of women SHGs. The company is the first Indian MFI to offer weather-based insurance to customers through a tie-up with an insurance company, and the first MFI with an institutional shareholding structure.

BSFL provides microfinance and knowledge-based technical assistance. Its customers include small and marginal farmers, rural artisans, micro-enterprises, and federations and cooperative owned by self-help groups (SHGs). As on September $30^{\text {th }}, 2011$, it had a presence in 10 states across India. 


\begin{tabular}{|l|l|}
\hline Year of Incorporation: & 1996 \\
\hline Year of commencement of microfinance operations: & 1997 \\
\hline Legal status: & Public Ltd. Co. (NBFC) \\
\hline Lending model: & Diversified \\
\hline Chief Executive : & Dr. Vijay Mahajan, Managing Director \\
\hline Auditor : & V. Nagarajan \& Co., Hyderabad \\
\hline
\end{tabular}

\section{Bandhan Financial Services Pvt. Ltd (BFSPL):}

In 2006, the founder of Bandhan, a non governmental organization (NGO) with microfinance operations, Acquired Ganga Niryat Pvt. Ltd., non-banking financial company (NBFC), and registered it has Bandhan financial Services Pvt. Ltd. (BFSPL). As on September 30, 2011, the MFI had loans outstanding of Rs.1328 million spread across 191 branches. The Bandhan group plans to consolidate its microfinance operations under BFSPL in 2009-10 (refers to financial year, April 1 to march 31).

BFSPL follows the group-based lending approach; its loan products are similar to those Bandhan. The NBFC's presence is largely restricted to West Bengal and Tripura and during first six months of 2008-09, it also opened branches in New Delhi and Bihar.

\begin{tabular}{|l|l|}
\hline Year of Incorporation: & 2006 \\
\hline Year of commencement of microfinance operations: & 2006 \\
\hline Legal status: & Public Ltd. Co. (NBFC) \\
\hline Lending model: & JLG \\
\hline Chief Executive : & $\begin{array}{l}\text { Mr. Chandra Sekhar Ghosh, Chairman and Managing } \\
\text { Director }\end{array}$ \\
\hline Auditor: & SRB 7 Associates, Kolkatta \\
\hline
\end{tabular}

\section{Cashpor Micro Credit (CMC):}

Cashpor Micro Credit (CMC) was promoted in 2002 as a subsidiary of Cashpor Financial and Technical services, and therefore transferred its microfinance operations, which it had started in 1997, to CMC operations in eastern Uttar Pradesh and western Bihar.

The MFI has developed an index, Cashpor Housing index (CHI), to help identify prospective members for lending. The MFI follows joint liability group (JLG) model and has adopted the best practices of both Grameen Bank and ASA models of Bangladesh. CMC offers three loan products, all at an interest rate of 27 per cent per annum (on reducing balance basis) and with tenure of 52 weeks. The loan amount ranges from Rs.1,000 to Rs.25, 000.

\begin{tabular}{|l|l|}
\hline Year of Incorporation : & 2002 \\
\hline Year of commencement of microfinance operations: & 1997 \\
\hline Legal status: & Section 25 company \\
\hline Lending model: & JLG \\
\hline Chief Executive : & Mr. J S Tomar, director \\
\hline Auditor : & M. Jaiswal \& Associates, Varanasi \\
\hline
\end{tabular}

\section{Grama Vidiyal Microfinance Pvt. Ltd. (GVMFL):}

Grama Vidiyal Microfinance Pvt. Ltd. (GVMFL) is a Tiruchirappalli based NBFC which started its microfinance operations in early 2008. During 2007-08 (refers financial year, April 1 to March 31), the Grama Vidiyal Trust (GVT), a leanding NGO-MFI in Tamil Nadu, which started its microfinance programme in 1996, transferred its entire loan portfolio to GVMFL. As of September 30, 2008, the MFI had more than 3,30,000 members across 126 branches in Taml Nadu.

GVMFL follows a modified version of the Grameen Bank model of lending and offers loans at 12 per cent interest (flat rate basis) rate per annum with tenures ranging from 10 weeks to 100 weeks. The loan size varies from Rs.1,000 to Rs.50,000 depending on the repayment capacity of individual borrowers. In addition, the MFI charges 3 per cent of loan amount as upfront free for all loans except special loans (SLs). In case of SLs, GVMFL collects 7.5 per cent upfront charges, and charges no interest. The MFI also offers lite insurance through a tie-up with an Indian private sector insurance company.

\begin{tabular}{|l|l|}
\hline Year of Incorporation : & 2007 \\
\hline Year of commencement of microfinance operations: & 1996 \\
\hline Legal status: & Private Ltd. Co. (NBFC) \\
\hline Lending model: & JLG \\
\hline Chief Executive : & $\begin{array}{l}\text { Mr. Arjun Muralidharan, } \\
\text { Chief Executive Officer }\end{array}$ \\
\hline Auditor : & V. Nagarajan \& Co., Tamil Nadu \\
\hline
\end{tabular}




\section{Grameen Financial Services Pvt .Ltd. (GFSPL):}

Grameen Financial Services Pvt. Ltd. (GFSPL) was incorporated 1991 as Sanni Collection Pvt. Ltd. It was acquired by its current management in 2007. Subsequently, in October 2007, GFSPL took over the microfinance programme of T.Muniswamappa Trust (TMT, Popularly known as 'Grameen Koota'). Grameen Koota started its microfinance programme in 1999, with seed capital support from Grameen Trust, Bangladesh.

GFSPL lends to ten-member groups under the Grameen Bank model of lending and offers three different loan product offerings to its clients. The MFI's core loan product is a 50-week loan with a flat interest rate of 12 per cent. The MFI charges an upfront fee of 1 to 3 per cent of the loan amount, depending up on the borrower profile (new or repeat) and the loan product. The company also provides health insurance companies. As on September 2008 the MFI had a borrower base of more than 1,50,000 borrowers across 17 districts of Karnataka. During second half of 2008-09 (refers to financial year, April 1 to March 31), the MFI has expanded its operations to Maharashtra and has piloted individual loans in two urban branches at Bangalore and Tumkur.

\begin{tabular}{|l|l|}
\hline Year of Incorporation : & 1998 \\
\hline $\begin{array}{l}\text { Year of commencement of } \\
\text { microfinance operations: }\end{array}$ & 1999 \\
\hline Legal status: & Private Ltd. Co. (NBFC) \\
\hline Lending model: & JLG \\
\hline Chief Executive : & Mr. Suresh K. Krishna, Managing Director \\
\hline Auditor : & M.S. Kamanth \& Associates, Bangalore \\
\hline
\end{tabular}

\section{Performance Evaluation of Select Microfinance Institutions:}

It is proposed to analyse the performance of select microfinance institutions. The data of eleven years (from 2001 to 2011) required for the analysis part have been collected through online database www.mixmarket.org. The analysis part is carried out with the help of the following variables:

\section{Operating efficiency:}

1. Cost per Borrower

2. Operating Expenses to Loan Portfolio

3. Operating Expenses to Assets

Productivity efficiency:

1. Number of Borrowers per Staff Member

2. Number of Active Borrowers

3. Average Loan Balance per Borrower

Financial Efficiency:

1. Debt-Equity Ratio

Overall Performance:

2. Gross Loan Portfolio to Assets

1. Yield on Gross Portfolio

For the purpose of the analysis of data pertaining to these MFIs, a study period from 2001 to 2011 has been chosen and various statistical techniques like Mean, one-way ANOVA have been performed for deriving at conclusion.

\section{Yield on Gross Portfolio:}

This ratio represent amount yielded in terms of percentage as to the gross loan portfolio. Higher the ratio indicates high profitability and efficient utilization of funds advanced to various self help groups and other individuals. The data pertaining to yield on gross portfolio are presented in table-1. 
Table-1

Yield on Gross Portfolio of sample Microfinance Institutions during the period from 2001 to 2011

(In percent)

\begin{tabular}{|c|c|c|c|c|c|c|c|c|c|c|r|}
\hline Years & SKS & Spandana & SML & AML & SKDRDP & BSFL & Bandhan & CMC & GVMFL & GFSPL & Mean \\
\hline $\mathbf{2 0 0 1}$ & & & & & & & & & & & \\
\hline $\mathbf{2 0 0 2}$ & & & & & & & & & & & \\
\hline $\mathbf{2 0 0 3}$ & 30.26 & 28.70 & 33.44 & & & & & & 29.76 & 37.06 & $\mathbf{3 1 . 8 4}$ \\
\hline $\mathbf{2 0 0 4}$ & 31.47 & 18.35 & 32.47 & & & & 24.67 & 24.70 & 29.66 & 36.08 & $\mathbf{2 8 . 2 0}$ \\
\hline $\mathbf{2 0 0 5}$ & 21.57 & 25.23 & 32.04 & 21.06 & 8.76 & 10.42 & 23.72 & 23.08 & 33.23 & 29.80 & $\mathbf{2 2 . 8 9}$ \\
\hline $\mathbf{2 0 0 6}$ & 23.77 & 13.55 & 14.96 & 14.97 & 10.05 & 15.05 & 27.01 & 19.27 & 28.78 & 31.51 & $\mathbf{1 9 . 8 9}$ \\
\hline $\mathbf{2 0 0 7}$ & 25.28 & 20.74 & 22.27 & 17.21 & 12.98 & 15.73 & 20.44 & 26.38 & & 25.60 & $\mathbf{2 0 . 7 4}$ \\
\hline $\mathbf{2 0 0 8}$ & 26.33 & 23.75 & 25.52 & 25.39 & 13.41 & 70.01 & 27.01 & 24.05 & 35.47 & 24.87 & $\mathbf{2 9 . 5 8}$ \\
\hline $\mathbf{2 0 0 9}$ & 25.64 & 25.71 & 31.48 & 25.64 & 13.55 & 16.85 & 20.16 & 24.44 & 28.36 & 17.73 & $\mathbf{2 2 . 9 6}$ \\
\hline $\mathbf{2 0 1 0}$ & 24.48 & 20.66 & 30.33 & 30.49 & 11.97 & 17.72 & 21.32 & & 34.41 & 25.91 & $\mathbf{2 4 . 4 4}$ \\
\hline $\mathbf{2 0 1 1}$ & 1.19 & & & & & & & & & & $\mathbf{1 . 1 9}$ \\
\hline Mean & $\mathbf{2 3 . 3 3}$ & $\mathbf{2 2 . 0 9}$ & $\mathbf{2 7 . 8 1}$ & $\mathbf{2 2 . 4 6}$ & $\mathbf{1 1 . 7 9}$ & $\mathbf{2 4 . 3 0}$ & $\mathbf{2 3 . 4 8}$ & $\mathbf{2 4 . 1 5}$ & $\mathbf{3 1 . 3 8}$ & $\mathbf{2 8 . 5 7}$ & $\mathbf{2 3 . 9 3}$ \\
\hline
\end{tabular}

Source: Compiled from the database developed by Microfinance Institutions Exchange (Mix market) for the period from 2001 to 11 .

Figure - 1

Yield on Gross Portfolio of Sample MFIs during the period from 2001 to 2011

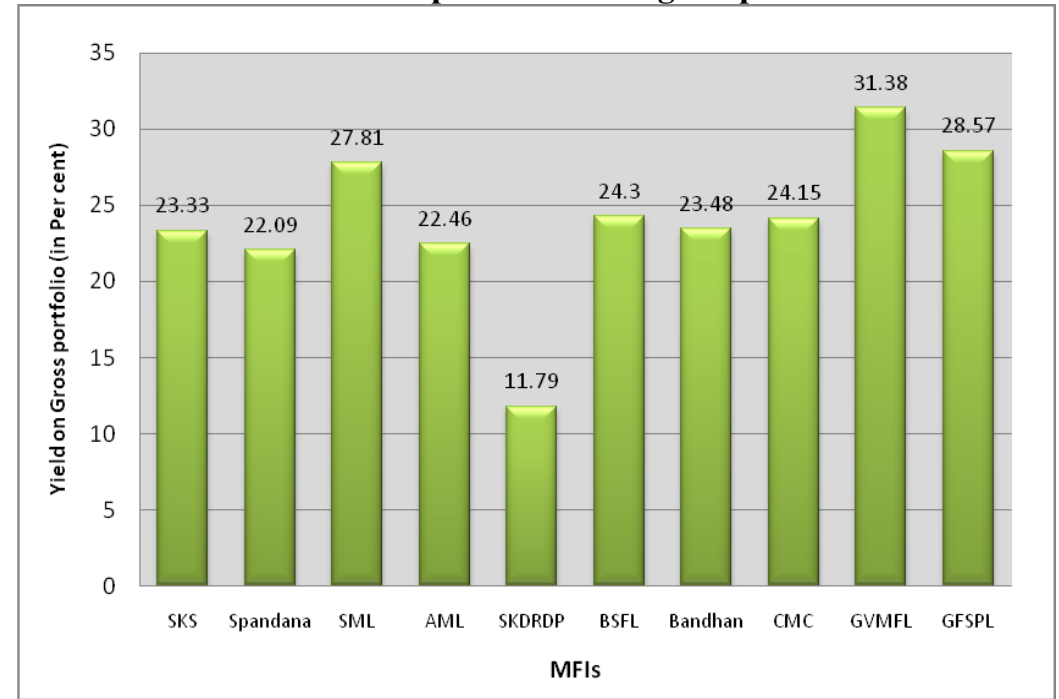

Source: Performed by using data of Mean Yield on Gross Portfolio compiled in table-1

On examination of data in table-1, it has been found that the percentage of yield on gross portfolio of the MFI industry has been varied between the highest of 31.84 per cent in 2003 and lowest 19.89 per cent in 2006 with industry aggregate of 23.93 per cent during the period from 2001 to 2011 .

Year wise analysis indicates the yield on gross portfolio of SKS ranged between 31.47 per cent and 1.19 per cent with yearly average of 23.33 per cent which is below the industry aggregate. Spandana accounted for yield ranging between 28.7 per cent and 13.55 per cent with yearly average of 23.09 per cent, lower than industry aggregate average. SML, AML, SKDRDP, BSFL, Bandhan, CMC, GVMFL, GFSPL were accounted for yield on gross portfolio varied between the highest of 33.44 per cent, 30.49 per cent, 13.55 per cent, 70.01 per cent, 26.38 per cent, 35.47 per cent, and 37.06 per cent respectively and lowest of 14.96 per cent, 14.97 per cent, 8.76 per cent, 10.42 per cent, 20.16 per cent, 19.27 per cent, 28.36 per cent, and 17.73 per cent respectively with the yearly average of 27.81 per cent, 22.46 per cent, 11.79 per cent, 24.3 per cent, 23.48 per cent, 24.15 per cent, 31.38 per cent, and 28.57 per cent respectively during the study period. Of these, the average yield on gross portfolio of SML (27.81 per cent), BSFL (24.30 per cent), CMC (24.15 per cent), GVMFL (31.38 per cent), and GFSPL (28.57 per cent) recorded above the industry aggregate average (23.93 per cent), which 
depicts that these MFIs were relatively different in achieving high yielding on gross portfolio as compared to that of other MFIs.

The mean yield on gross portfolio pertaining to these sample MFIs are analysed by performing oneway ANOVA and are tested with the following null hypotheses. The results are depicted in table-2.

Table-2

ANOVA- Results of Yield on Gross Portfolio

\begin{tabular}{|l|c|c|c|c|}
\hline \multicolumn{5}{|c|}{ SUMMARY } \\
\hline \multicolumn{1}{|c|}{ Groups } & Count & Sum & Average & Variance \\
\hline SKS & 9 & 209.99 & 23.33222 & 78.40204 \\
\hline Spandana & 8 & 176.69 & 22.08625 & 22.88546 \\
\hline SML & 8 & 222.51 & 27.81375 & 41.7404 \\
\hline AML & 6 & 134.76 & 22.46 & 33.76016 \\
\hline SKDRDP & 6 & 70.72 & 11.78667 & 3.875787 \\
\hline BSFL & 6 & 145.78 & 24.29667 & 507.9729 \\
\hline Bandan & 7 & 164.33 & 23.47571 & 8.554162 \\
\hline CMC & 7 & 169.02 & 24.14571 & 6.505195 \\
\hline GVMFL & 7 & 219.67 & 31.38143 & 8.465781 \\
\hline GFSPL & 8 & 228.56 & 28.57 & 40.8184 \\
\hline
\end{tabular}

\begin{tabular}{|c|c|c|c|c|c|c|}
\hline \multicolumn{7}{|l|}{ ANOVA } \\
\hline Source of Variation & SS & $\mathrm{df}$ & MS & $\mathrm{F}$ & P-value & F crit \\
\hline Within Groups & 4234.5214 & 62 & 68.29873 & & & \\
\hline
\end{tabular}

Source: ANOVA Performed by using MS-Excel software based an the data compiled in table-1

Ho: There is no significance difference among the Mean yield on Gross portfolio pertaining to SKS, SPANDANA, SML, AML, SKDRDP, BSFL, BANDHAN, CMC, GVMFL, and GFSPL microfinance institutions.

\section{Inference:}

As the calculated value of $\mathrm{F}=2.614718$ is greater than table value of $\mathrm{F}$ crit $=2.034774$, there is significance difference in the yield on Gross portfolio of sample microfinance institutions at $5 \%$ level of significance, thereby rejecting the null hypothesis.

\section{Conclusions:}

The average yield on gross portfolio of SML (27.81 per cent), BSFL ( 24.30 per cent), CMC ( 24.15 per cent), GVMFL (31.38 per cent), and GFSPL (28.57 per cent) recorded above the industry aggregate average (23.93 per cent), which depicts that these MFIs were relatively different in achieving high yielding on gross portfolio as compared to that of other MFIs.

There is no significance difference among the Mean yield on Gross portfolio pertaining to SKS, SPANDANA, SML, AML, SKDRDP, BSFL, BANDHAN, CMC, GVMFL, and GFSPL microfinance institutions. As the calculated value of $\mathrm{F}=2.614718$ is greater than table value of $\mathrm{F}$ crit $=2.034774$, there is significance difference in the yield on Gross portfolio of sample microfinance institutions at $5 \%$ level of significance, thereby rejecting the null hypothesis.

\section{References}

[1]. Prof Zohra Bi \& Dr Syam Lal Dev Pandey (2011), Comparison of Performance of Microfinance Institutions with Commercial Banks in India, Australian Journal of Business and Management Research Vol.1 No.6 [110-120], September-2011.

[2]. Pankaj K Agarwal and S.K.Sinha (2010), the Financial Performance of Microfinance Institutions in India Delhi Business Review X Vol. 11, No. 2 (July - Desember 2010).

[3]. Fisher, Thomas and M.S. Sriram ed., (2002), Beyond Micro-credit: Putting Development Back into Microfinance.

[4]. Harper, Malcolm, (2002), "Promotion of Self Help Groups under the SHG Bank Linkage Program in India", Paper presented at the Seminar on SHG-bank Linkage Programme at New Delhi, November 25-26, 2002.

[5]. Kabeer N (2001), "Conflicts Over Credit: Re-evaluation the Empowerment Potential of Loans to Women in Rural Bangladesh": World Development, Vol.29, No.1.

[6]. Mayoux, L (2001), "Talking the Down Side: Social Capital, Women's Empowerment and Microfinance in Cameroon" Development and Change, Vol.32, Institute of Development Studies, Oxford, Pp 435-64.

[7]. New Delhi: Vistaar Publications; Oxford: Oxfam.

[8]. Yaron, Jacob (1994), "What Makes Rural Finance Institutions Successful", the World Bank Research Observer, Vol.9, No. 1, January, Pp.49-70. 